\title{
特集 荷電膜の性質
}

\section{荷電膜表面の電気化学的性質}

\section{松本英俊}

東京工業大学大学院理工学研究科 ₹152-8552 東京都目黒区大岡山2-12-1-S8-27

\section{Surface Electrochemical Properties of Charged Membranes}

\section{Hidetoshi Matsumoto}

Department of Organic and Polymeric Materials, Tokyo Institute of Technology, 2-12-1-S8-27, Ookayama, Meguro-ku, Tokyo 152-8552, Japan

Surface electrochemical property, which is represented as $\zeta$-potential or surface charge density, is a key parameter in membrane science. Charge on membrane surface plays an important role in the separation performance and fouling tendency. Electrokinetic measurements are a straightforward and powerful method to provide information about charge characteristics at the membrane-solution interface. This method also has higher sensitivity than the spectroscopic surface analysis methods (e.g., SEM, EDX, and FT-IR). Therefore, the electrokinetic characterization can be widely used for not only separation membrane surfaces and biocompatible interfaces, but also nano-engineered surfaces. Here, we presented general remarks on electrokinetic characterization of charged membranes based on streaming potential measurements, focusing on amphoteric charged membranes.

Key words : surface electrochemical property / charged membrane / zeta potential/streaming potential/ amphoteric charged membrane

\section{1.はじめに}

高分子膜の表面には種々の荷電基が存在する (Fig. 1).このような荷電基は, 化学的に導入さ れた官能基の他に，重合時に使用したモノマー， 開始剤，触媒などの残留によるもの1,2)，製膜工 程において発生したもの ${ }^{3)}$, 溶液中のイオンが吸 着したものが含まれる，従って，ほとんどすべて の高分子表面にはなんらかの荷電基が存在してい ると言っても過言ではない. 膜表面の荷電基はイ オン選択性, 耐ファウリング性, 抗血栓性などの 機能発現において重要な役割を果たしており,
SEM, EDX, FT-IRなどの分析法において検出下 限以下の量であっても, 膜機能に大きな影響を与 えることが指摘されている4).

界面動電位（ゼー夕電位）は，溶液中での膜表 面の電気化学的性質を, 簡便かつ高精度に評価で きる強力な手段である。ゼ一夕電位は, 逆浸透膜 や各種ろ過膜など分離膜表面のキャラクタリゼー ションに広く利用されており, 特に耐ファウリン グ性膜開発の重要な指針となっている4). 近年で は，バイオ界面における表面電荷と血液適合性, 免疫反応, 細胞の接着・増殖性などの関係への関 心から，生体適合性マテリアル表面のキャラク夕 
- Strong electrolyte

$\begin{array}{lll}\text {-sulfonic acid } & \\ \text {-quaternary amine } & \mathrm{SO}_{3}^{-} \\ \text {-quatemary pyridine } & -\mathrm{NR}_{3}^{+} \\ \text {-quatemary imidazole } & \\ \text {-carboxylic acid } & -\mathrm{COOH}_{2} & \\ \text {-amine (primary tertiary) } & -\mathrm{NR}_{2}-\mathrm{NHR}-\mathrm{NH}_{2} \\ \text {-phosphoric acid } & -\mathrm{PO}_{3} \mathrm{H}_{2} & \\ \text {-phenol } & \mathrm{OH}\end{array}$

Fig. 1 Fixed-charge groups on membrane surfaces.

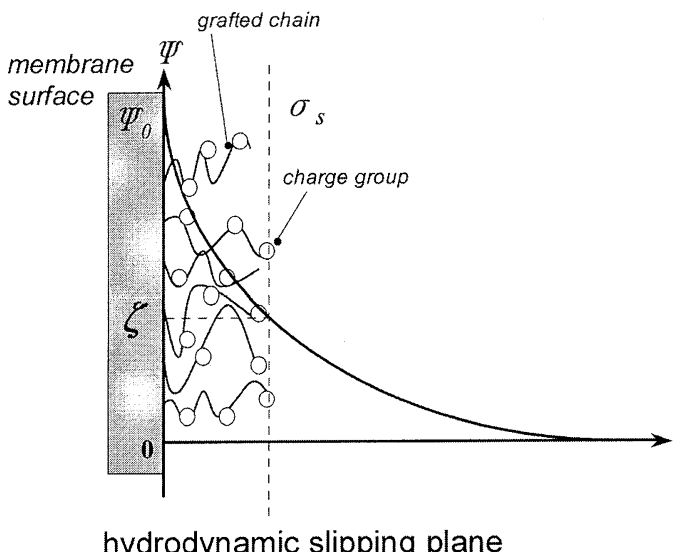

hydrodynamic slipping plane

Fig. 2 Schematic model of potential distribution at polyelectrolyte-grafted surface.

\section{Cationic}

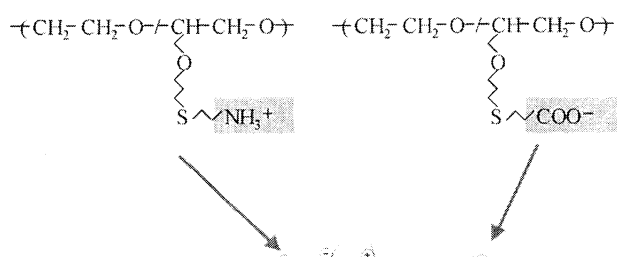

\section{Amphoteric}

\section{Charged Surface}

\section{Amphoteric}

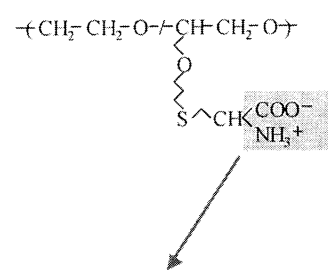

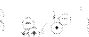

mixed grafted chain (MGC) type amphoteric ion-pair side chain (ASC) type
（圧力）によって移動す る際に誘起される電位で あり，膜/溶液界面にお ける荷電構造に関する情 報をin situ で高感度に 反映する．圧力 $\Delta P$ を加 えたときに発生する流動 電位 $\Delta E$ は HelmholtzSmoluchowski の式によ ってら電位と関係付けら れる。

Fig. 3 Architecture of surface modification using polyelectrolytes.

$$
\frac{\Delta E}{\Delta P}=\frac{\varepsilon \zeta}{\eta \lambda}
$$

リゼーション法としても注目されている5).

本稿では, 流動電位法を用いたゼー夕電位測定 に基づく膜表面の電気化学的なキャラクタリゼー ションについて, 著者らが行ってきた両性荷電 (アンフォテリック) 膜系の研究を中心に解説 する。

\section{2. 流動電位法を用いたゼータ電位測定6)}

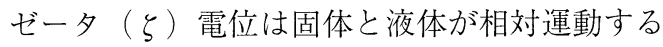
際に固液界面（流体力学的なすべり面）に生じる 電位差である (Fig. 2)。流動電位は, 荷電表面近 傍の溶液中に形成される拡散電気二重層が外場 $\varepsilon:$ 溶液の誘電率, $\eta$ : 溶液粘度, $\lambda:$ 溶液の電 気伝導度

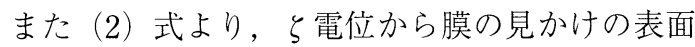
荷電密度 $\left(\nabla_{s}\right)$ を求めることができる.

$$
\nabla_{s}=\frac{2 \varepsilon k T \kappa}{e} \sinh \left(\frac{e \zeta}{2 k T}\right)
$$

$\varepsilon$ : 溶液の誘電率, $\kappa:$ Debye遮蔽長, $e:$ Coulomb電荷, $k$ : Boltzmann係数, $T$ : 絶対温度 
(a) ASC type

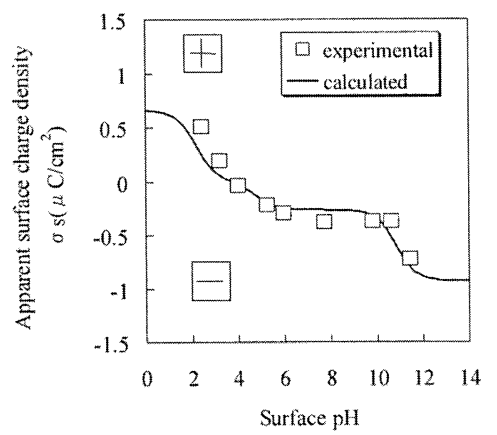

(b) MGC type

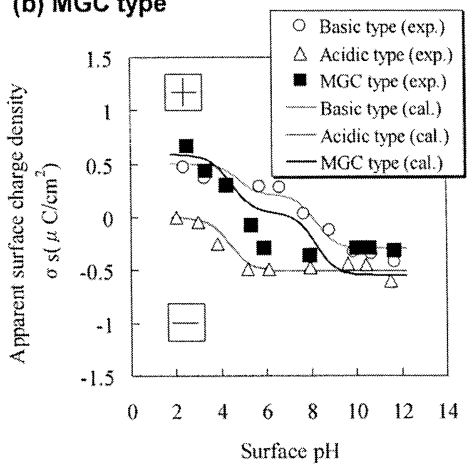

Fig. 4 The pH-dependence of the apparent surface charge density for (a) the ASC type and (b) the MGC type amphoteric charged membranes.

(a) Anionic molecule

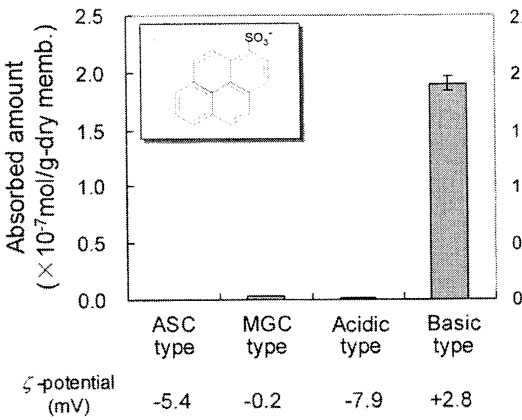

(b) Cationic molecule

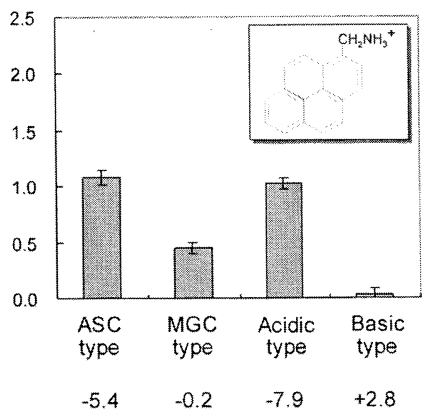

Fig.5 Adsorbed amount of ionic organic molecules on the membrane surfaces at $\mathrm{pH} 5.6$ : (a) anionic molecule (1-pyrenesulfonic acid) and (b) cationic molecule (1-pyrenemethylamine).

なっていない.

著者らはFig. 3に示すよう な高分子電解質を用いた両 性荷電表面のアーキテクチ ユアを提案し7), ゼー夕電位 を用いた膜表面のキャラク タリゼーションについて研 究を進めている3,7 11)。ここ では, 膜表面に両性高分子 電解質をグラフトした膜 (amphoteric ion-pair side chain, ASC型）とカチオン性 高分子電解質とアニオン性 高分子電解質の両方をグラ フトした膜 (mixed grafted chain, MGC型) の2種類の両 性膜を調製した。高分子電 解質には，荷電基の異なる3 種類のイオン性ポリエチレ ングリコール誘導体を，基 材にはポリエチレン多孔膜 を使用した。

\section{2 ゼータ電位による膜} 表面のキャラクタリ ゼーション 3,7$)$

ゼー夕電位によって両性 荷電膜表面の電気化学的な 性質を評価した。ここでは, ゼー夕電位から得られた見かけの表面荷電密度 $\sigma_{s}$ について, 表面イオン性基の解離挙動に基づ 〈Site Dissociation Model (SDM) 6) を用いて解析 を行った。膜/溶液界面におけるイオン性基の解 離平衡は以下のように表される。

酸性基：

$$
A H \leftrightarrow A^{-}+H^{+} \quad K_{a}=\frac{\left[A^{-}\right]\left[H^{+}\right]_{s}}{[A H]}
$$

塩基性基：

$$
B H^{+} \leftrightarrow B+H^{+} \quad K_{b}=\frac{[B]\left[H^{+}\right]_{s}}{\left[B H^{+}\right]}
$$
性膜の荷電構造はきわめて複雑であるため, 現状 では，その電気化学的な性質はほとんど明らかに 
(a) $\mathrm{pH} 3.3$

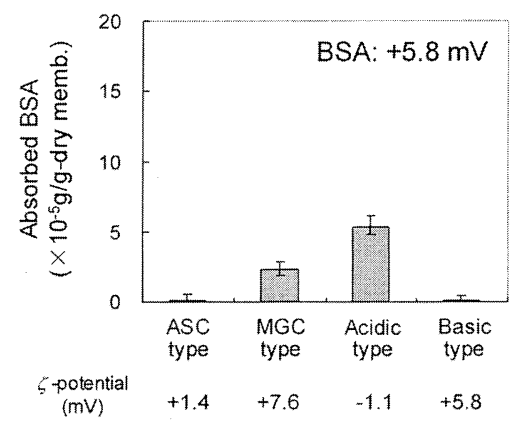

(b) $\mathrm{pH} 7.2$

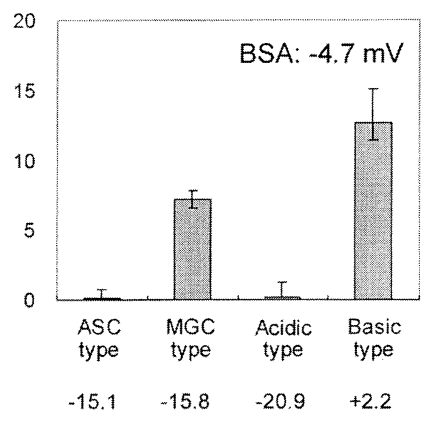

Fig. 6 Adsorbed BSA on the membrane surfaces in (a) $10 \mathrm{mM}$ acetate buffer ( $\mathrm{pH} 3.3$ ) and (b) $10 \mathrm{mM}$ phosphate buffer ( $\mathrm{pH} \mathrm{7.2).}$ (a) Experimental

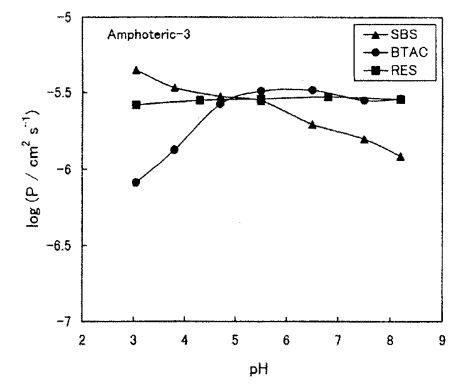

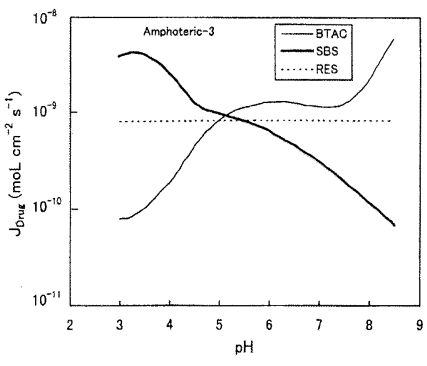

(b) Theoretical

Fig. 7 The fluxes of the drugs through amphoteric charged membranes: (a) experimental and (b) theoretical results. SBS: sodium benzensulfonate (anionic molecule), BTAC : benzyltrimethyl ammonium chloride (cationic molecule), RES: resorcinol (nonionic molecule).

Fig. 4に両性荷電膜の見かけの表 面荷電密度 $\sigma_{s}$ の $\mathrm{pH}$ 依存性を示 す. ASC型膜の $\sigma_{s}-\mathrm{pH}$ プロファ イルは, pH6-11において両性荷 電膜に特徵的なプラトーな領域 を示して㧍り，SDMを用いた計 算結果も，実験結果と良い一致 を示した。一方, MGC型膜の $\sigma_{s}-\mathrm{pH}$ プロファイルは, 単独荷 電のBasic型とAcidic型の中間的 な挙動を示しており，単独荷電 のpH>5で実験結果と計算結果 の間にずれが生じた。このずれ は，MGC型膜表面において， $\mathrm{pH}$ 変化に伴いカチオン鎖とアニ オン鎖のコンフォメーション変 化がおこるために生じると考え られる ${ }^{3)}$ 。ここでは, 解離定数 として文献值12)を用いたが, SDM解析により，ゼー夕電位の $\mathrm{p} \mathrm{H}$ 依存性から, 膜表面に存在 する解離性荷電基密度 $(N)$ 抒 よび解離定数 $(K)$ を求めるこ とも可能である。

\section{3 表面電荷と溶質分子吸着 性および透過性}

イオン性有機分子㧍よびタン パク質（ウシ血清アルブミン，

SDMは，全てのイオン性サイトが同一平面上に 存在するという仮定に基づいており，見かけの表 面荷電密度 $\left(\nabla_{S}\right)$ は次式で表される.

$$
\begin{aligned}
\sigma_{s} & =-e \sum_{i}\left[A^{-}\right]_{i}+e \sum_{j}\left[B H^{+}\right]_{j} \\
& =\sum_{i}\left[\frac{-e N_{a}}{1+\left[H^{+}\right]_{s} / K_{a}}\right]+\sum_{j}\left[\frac{e N_{b}}{1+K_{b} /\left[H^{+}\right]_{s}}\right]
\end{aligned}
$$

$N$ : 解離性サイト密度, $\left[H^{+}\right]_{s}$ 膜表面での水素イオン 濃度
BSA）の両性荷電膜表面への吸着量を測定し，表 面電荷との関係を調べた。イオン性有機分子の膜 への吸着性は膜表面のゼー夕電位と良い相関を示 した $(\text { Fig. 5) })^{8)}$ 。また，アルブミンの膜への吸着 性も，概ね膜表面のゼ一夕電位と良い相関を示し た (Fig. 6) ${ }^{9)}$.これらの結果は，膜表面へのイオ ン性分子の吸着において静電相互作用が重要な役 割を果たしていることを毫付けている，尚，アル ブミンの MGC型膜への吸着に見ら林ゼー夕電 位との矛盾は，3.2節で述べたこの膜の界面荷電 構造に起因する ${ }^{9)}$.

Jimboらは，種々のpH条件下に扔いて両性荷電 膜を透過するイオン性薬物の流束を測定し，流動 
電位より得られたゼー夕電位を用いたNernstPlanckの式に基づく計算結果との比較を行った ${ }^{11)}$. Fig. 7に示すように，流束の実験結果と測定結果 は定性的に一致しており，ゼ一夕電位により，イ オン性分子の透過が予測可能であることを示して いる.

\section{4. おわりに}

近年，ナノテクノロジーを用いた界面制御技術 の進展は著しい。ゼー夕電位は，このようなナノ スケールで構造制御されたマテリアル界面のキャ ラクタリゼーションにも有望な分析手段である. 現在著者らは，電場を利用したナノ加工技術であ るエレクトロスプレー・デポジション (ESD) 法13)により作製したプロテインチップ14)につい てゼー夕電位に基づくセンシング法の開発を進め ている15).

\section{謝 辞}

本研究を遂行するにあたり，終始ご指導頂きま した東京工業大学大学院理工学研究科, 谷岡明彦 教授に深く感謝致します。膜の表面修飾に使用し たイオン性ポリエチレングリコール誘導体の合成 については大妻女子大学，小山義之教授にご指導 を賜りました。また，流動電位測定については日 本ゼオン株式会社, 神保俊彦博士より多くのご助 言と暖かい励ましを賜りました。愿くお礼申し上 げます。

\section{文献}

1) Fang SJ, Fujimoto $K$, Kondo S, Shiraki $K$, Kawaguchi H : Colloid Polym. Sci., 278 864-871 (2000)

2) Kurihara M, Fusaoka Y : Membrane, 24 247-255 (1999)

3) Matsumoto H, Koyama Y, Tanioka, A : Colloids Surf. A, 222 165-173 (2003)

4) Ikeda $K$, Hachisuka $H$, Nakamura $T$, Kimura $S$, Ueyama K: J. Chem. Eng. Jpn., 32 581-587 (1999)

5) Werner C, König U, Augsburg, Arnhold C, Körber H, Zimmermann R, Jacobasch HJ : Colloids Surf. A, 159
519-529 (1999)

6) Hunter RJ : "Zeta Potential in Colloid Science: Principles and Applications", Academic Press, London (1981) ; Lyklema J : "Fundamentals of Interface and Colloid Science, Vol.2, Solid-Liquid Interfaces", Academic Press, London (1995)

7) Matsumoto H, Koyama Y, Tanioka, A : Langmuir, 17, 3375-3381 (2001)

8) Matsumoto H, Koyama Y, Tanioka, A : Langmuir, 18, 3698-3703 (2002)

9) Matsumoto H, Koyama Y, Tanioka, A : J. Colloid Interface Sci., 264 82-88 (2003)

10）松本英俊, 谷岡明彦：高分子加工，51 401-405 (2002)

11) Jimbo $T$, Ramirez $P$, Tanioka $A$, Mafè $S$, Minoura $N$ : J. Colloid Interface Sci., 225 447-454 (2000)

12) Martell AE, Smith RM : "Critical Stability Constants”, Plenum Press, New York, Vol.1 (1974), Vol.2 (1975), Vol.3 (1977)

13）山形 豊, 松本英俊: 高分子, 52 829-832（2003）

14) Uematsu I, Matsumoto $H$, Morota $K$, Minagawa $M$, Tanioka A, Yamagata, Y, Inoue K : J. Colloid Interface Sci., 269 336-340 (2004)

15) Tanioka A, Uematsu I, Morota $K$, Matsumoto $H$, Yamagata $\mathrm{Y}$, Inoue $\mathrm{K}$ : Abstracts of International Symposium on Electrokinetic Phenomena (ELKIN 2002), Cracow, Poland, August 18-22, 79 (2002)

\section{（受付2004年9月1日＼cjkstart揭載決定9月6日）}

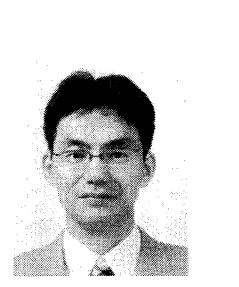

\section{著者略歴}

松本英俊（まつもと ひでとし）

1996年 東京工業大学大学院理工 学研究科有機材料工学専攻修士課 程修了

1996年～1999年 株式会社トクヤ

マ化学技術研究所研究員

2002 年 東京工業大学大学院理工学研究科有機・高分 子物質専攻博士課程修了 (博士 (工学)).

同年 東京工業大学大学院理工学研究科有機・高分子 物質専攻助手.

専門 高分子界面物性, 高分子荷電膜, 高分子ナノフ アブリケーション. 